\title{
KAJIAN TERHADAP OPERASIONAL KAPAL TRAWL DI PERAIRAN LAUT ARAFURA*)
}

\author{
Wedjatmiko"1) dan Sukarniaty²) \\ 1) Peneliti pada Balai Riset Perikanan Laut, Muara Baru-Jakarta \\ 2) Teknisi pada Balai Riset Perikanan Laut, Muara Baru-Jakarta
}

Teregristrasi I tanggal: 21 Maret 2005; Disetujui terbit tanggal: 21 Maret 2005

\begin{abstract}
ABSTRAK
Perairan Laut Arafura adalah merupakan sentra penangkapan udang dan ikan dasar (perikanan demersal) di kawasan Indonesia bagian timur. Berdasarkan pada komposisi hasil tangkapan menggunakan alat tangkap trawl (alat tangkap khusus untuk perikanan demersal) di perairan Arafura, menunjukkan bahwa jenis ikan yang merupakan hasil tangkapan sampingan sangat dominan (98.31\%), sedangkan udang yang menjadi tujuan utama penangkapan hanya mencapai $1,69 \%$. Sementara itu, komposisi hasil tangkapan non ikan (krustasea). menunjukkan bahwa hasil tangkapan udang yang komersial hanya $(6,38 \%)$. Udang non komersial $(5,62 \%)$ dan krustasea lain berupa rajungan, kepiting, dan udang mantis adalah sangat dominan (88\%). Fenomena tersebut pada umumnya merupakan indikator penurunan populasi udang di perairan Arafura. Dampak eksploitasi kapal traw/ terhadap usaha perikanan budi daya, antara lain pemanfaatan hasil tangkapan sampingan dapat digunakan sebagai tepung ikan yang merupakan bahan baku pakan buatan (pelet). Di mana pakan buatan adalah faktor yang sangat berperan untuk kegiatan budi daya perikanan. Sedangkan berdasarkan pada operasional banyak lokasi perairan yang tidak terjamah oleh aktivitas trawl, sehingga banyak lokasi yang dapat dimanfaatkan sebagai lokasi budi daya laut. Demikian juga banyak terdapat sumber daya induk komoditas perikanan budi daya. Secara tidak langsung dampak eksploitasi kapal trawl di perairan Laut Arafura, sangat berpengaruh positif terhadap usaha perikanan budi daya, apabila dikelola secara optimal.
\end{abstract}

KATA KUNCI: trawl, Laut Arafura, ikan demersal, udang, hasil tangkapan sampingan

\section{PENDAHULUAN}

Perairan Laut Arafura dan sebagian Maluku merupakan salah satu daerah penangkapan udang dan ikan demersal yang potensial. Usaha penangkapan udang di Laut Arafura sudah sejak lama dilakukan melalui patungan antara Indonesia dengan Jepang dan dalam pengembangan dewasa ini sudah banyak usaha PMDN. Basis operasional kapal penangkapan ikan semula terdapat di Sorong, Ambon, Tual, dan Benjina. Beberapa tahun terakhir ini, basis penangkapan ikan berkembang ke daerah Bintuni-Merauke, Kendari, dan Bitung. Jenis alat tangkap yang berkembang di perairan Arafura sebagian besar adalah alat tangkap ikan demersal (ikan dasar dan udang). Komoditas udang pada umumnya merupakan tujuan penangkapan dari alat tangkap tersebut, karena udang mempunyai nilai ekonomis tinggi dan merupakan komoditas ekspor.

Traw/merupakan salah satu jenis alat tangkap ikan yang paling efektif untuk menangkap ikan dasar dan udang. Bagian utama jaring traw/ terdiri atas sayap, badan, dan kantong yang dioperasikan dengan jalan ditarik menggunakan kapal. Problema penangkapan udang secara komersial dengan kapal trawl di beberapa negara Asia Tenggara adalah banyak ikan demersal sebagai hasil tangkapan sampingan yang dibuang percuma (Pauly \& Neal, 1985). Disebutkan pula ada asosiasi yang erat antara stok udang dengan ikan demersal. Naamin \& Sumiono (1983) mengatakan banyak hasil tangkapan sampingan di Laut Arafura diperkirakan mencapai $80 \%$ dari hasil tangkapan keseluruhan atau rata-rata 19 kali lebih besar dari hasil tangkapan udang. Selanjutnya Widodo (1997) mengatakan bahwa produksi hasil tangkapan sampingan di perairan Arafura diperkirakan antara 40.000 sampai dengan 70.000 ton setiap tahun. Sebagian dari hasil tangkapan sampingan tersebut dapat digolongkan ke dalam kelompok ikan demersal konsumsi. Jumlah tangkapan ikan demersal dan udang sejak beberapa tahun terakhir dapat diperkirakan mencapai lebih 300.000 ton per tahun, mengingat kapal pukat yang beroperasi saat ini sudah mencapai lebih dari 1.100 buah (Anonymous, 2001).

Evaluasi dan pengelolaan terhadap sumber daya udang peaneid dan hasil tangkapan sampingan di perairan Arafura mutlak diperlukan, mengingat penangkapan udang dan ikan demersal telah dilakukan dengan intensif yang melibatkan berbagai bentuk armada penangkapan, di samping itu pengelolaan yang disertai dengan pengendalian penangkapan belum memadai. Pengkajian udang di Laut Arafura antara lain pernah dilakukan oleh Naamin (1984); Komisi Nasional Pengkajian Sumber Daya Ikan (Anon., 2001). Pengkajian tersebut mengatakan bahwa intensitas pemanfaatan sumber daya udang 
telah berada pada tingkat yang tinggi, hal yang sama terjadi pula pada sumber daya jenis-jenis ikan demersal. Evaluasi ulang terhadap sumber daya udang dan ikan demersal di Laut Arafura perlu dilakukan untuk memberikan masukan dalam penyempurnaan kebijakan pengelolaan sumber daya ikan tersebut agar tujuan pengelolaan sebagaimana tertera dalam Undang-Undang Perikanan tahun 1985 tercapai serta dalam implementasi undang-undang mengenai otonomi daerah.

\section{DAERAH PENANGKAPAN}

Perikanan pukat udang (traw) tipe double rig trawl maupun stern traw/ telah berkembang sejak dekade tahun 1970-an, dimulai dengan perusahaan (join venture) yang berpangkalan di beberapa kota pelabuhan seperti Sorong, Ambon, Makassar, dan Kendari. Dalam perkembangan beberapa perusahaan telah memindahkan pangkalan dari Ambon ke Kendari maupun Tual, Merouke, dan Bitung, yaitu semenjak keamanan di Ambon kurang kondusif. Perubahan strategi penangkapan udang di Laut Arafura sejalan dengan permintaan pasar di negara pengimpor terutama Jepang, gejolak harga udang di pasar Internasional serta ketersediaan stok udang di laut. Daerah operasi penangkapan jaring trawl di perairan Laut Arafura dapat dilihat pada Gambar 1.

\section{AKTIVITAS PENANGKAPAN TRAWL}

Apabila dilihat cara operasi alat tangkap trawl, yaitu dengan cara menyapu atau menarik jaring dari kapal yang bergerak, maka sangat memungkinkan semua biota yang ada di dasar perairan akan tersapu bersih dan substratpun akan teraduk-aduk (Gambar 2).

Berdasarkan pada aktivitas tersebut dapat menyebabkan beberapa penurunan sumber daya

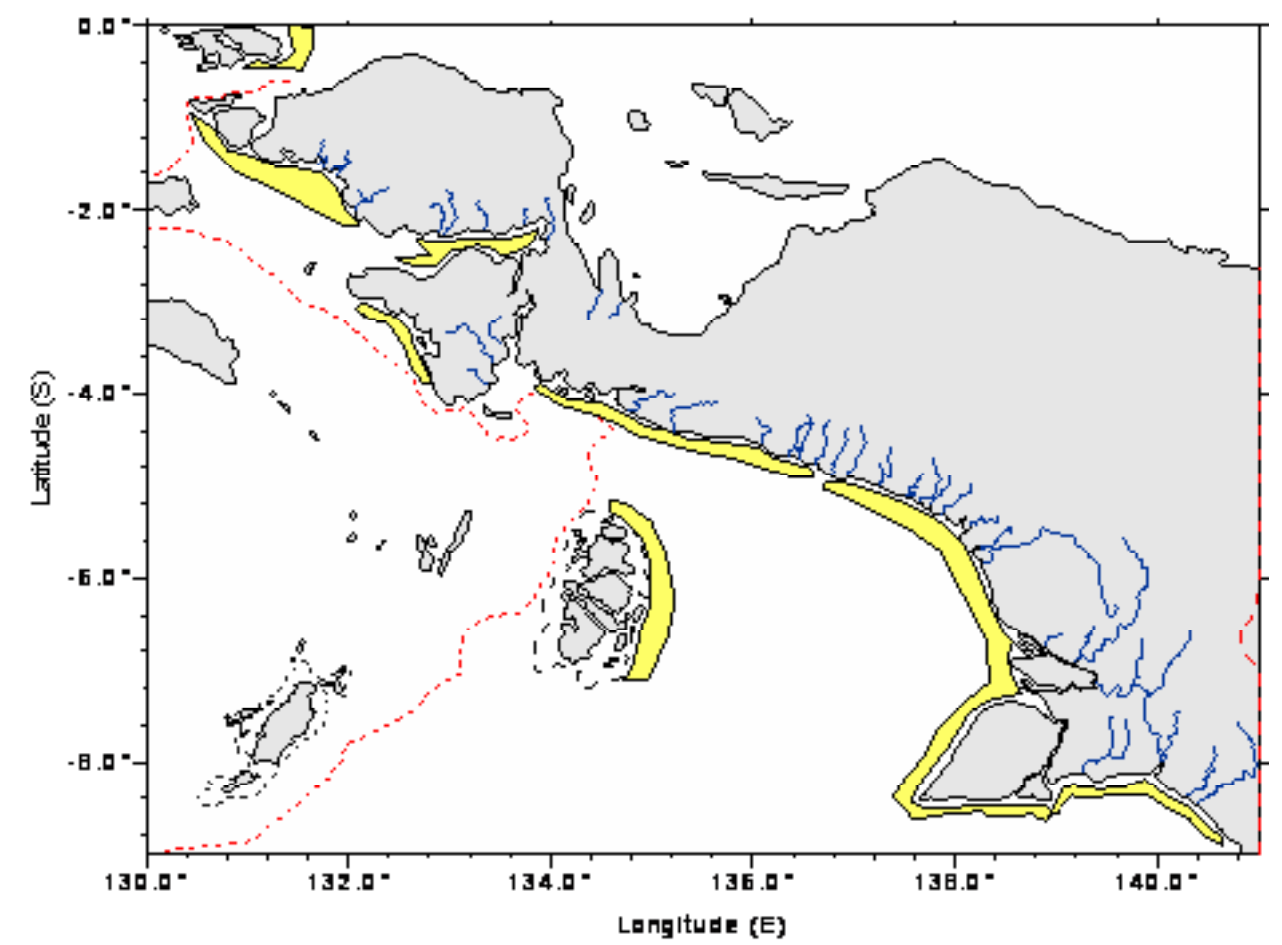

Gambar 1. $\quad$ L L Lokasi penangkapan udang menggunakan trawl di perairan Arafura.

perikanan yang diakibatkan oleh beberapa faktor sebagai berikut:

1. Penurunan populasi ikan baik jenis maupun densitas, hal ini disebabkan jaring yang tidak selektif, di mana semua jenis ikan (terutama ikan demersal) dan ukuran ikan yang relatif kecilpun dapat tertangkap oleh jaring tersebut. Penurunan populasi juga dapat disebabkan oleh luas daerah operasional akibat sapuan trawl.
2. Hilang, menurun, atau berpindah fishing ground akibat aktivitas penangkapan maupun oleh berkurang populasi ikan yang tertangkap jaring trawl.

3. Hilang, menurun, atau berpindah spawning ground yaitu tempat bertelur atau memijah berbagai jenis ikan, akibat penangkapan maupun aktivitas trawl, mengingat semua ukuran ikan tertangkap baik ukuran induk maupun ukuran anakan. 


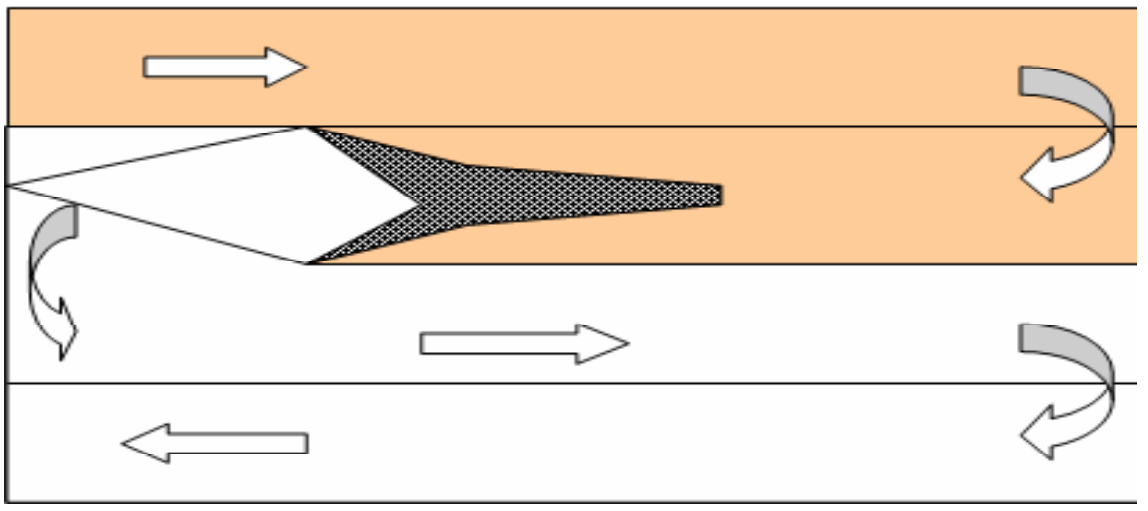

Gambar 2. Daerah sapuan oleh aktivitas operasional trawl.

4. Penurunan daya dukung perairan (carying capacity) akibat teraduk perairan tersebut oleh aktivitas trawl.

Berbeda dengan daerah perikanan budi daya yang pada umumnya lebih stagnan, aman, tingkat kesuburan tinggi, dan daya dukung perairanpun tetap tinggi. Daerah perikanan budi daya bukan merupakan daerah operasi penangkapan ikan menggunaan trawl. Lokasi perikanan budi daya laut yang cocok pada umumnya adalah di bawah 12 mil laut, perairan teluk, selat, dan daerah terlindung lain, serta perairan jernih.

\section{KOMPOSISI HASIL TANGKAPAN}

Tujuan utama alat tangkap trawl adalah untuk menangkap udang, namun hasil tangkapan jauh lebih banyak ikan demersal yang bukan merupakan sasaran penangkapan. Sebagian besar hasil tangkapan tersebut dibuang kembali ke laut dan hanya sebagian kecil yang dimanfaatkan. Hasil tangkapan ikan selain udang sering diistilahkan sebagai hasil tangkapan sampingan. Faktor utama yang mendorong ikan sebagai hasil tangkapan sampingan adalah harga ikan yang jauh lebih rendah jika dibandingkan dengan udang. Kecuali itu kapasitas palkah pada armada trawl terbatas dan lebih diutamakan untuk menyimpan udang.

Usaha penangkapan udang selalu memberikan hasil tangkapan sampingan yang volume jauh lebih besar dari hasil udang. Pauly \& Neal (1985) mengatakan problema penangkapan udang secara komersial dengan kapal traw/di beberapa negara Asia Tenggara adalah banyak ikan demersal sebagai hasil tangkapan sampingan yang dibuang percuma. Persentase hasil tangkapan sampingan bervariasi menurut daerah penangkapan dan waktu, Menurut Allsopps (1982) di daerah tropis rata-rata rasio hasil tangkapan sampingan terhadap udang berkisar 10:1.

Hasil tangkapan sampingan pada penangkapan udang di perairan Arafura sebagian besar berupa ikan demersal yang terdiri atas berbagai jenis dan ukuran, di mana kontribusi cukup besar dan belum dimanfaatkan secara optimal, sebagian besar dibuang kembali ke laut. Naamin \& Sumiono (1983) mengatakan banyak hasil tangkapan sampingan di Laut Arafura diperkirakan mencapai $80 \%$ dari hasil tangkapan keseluruhan atau rata-rata 19 kali lebih besar dari hasil tangkapan udang. Menurut Widodo (1997) pada tahun 1991 hasil tangkapan sampingan bervariasi antara 8 sampai dengan 13 kali hasil tangkapan udang dengan estimasi produksi antara tahun 1973 sampai dengan 198940.000 sampai dengan 170.000 ton setiap tahun.

Penelitian pada bulan Oktober sampai dengan Nopember 1992 di sub lahan Sele dan Bintuni memperoleh rasio hasil tangkapan sampingan terhadap udang 9:1. Dominasi jenis hasil tangkapan sampingan adalah ikan tigawaja (familia Sciaenidae), ikan lidah (Soleidae), dan nomei (Harpodontidae), Sementara itu, di perairan Kaimana pada periode yang sama lebih banyak tertangkap ikan petek (Leiognathidae), tigawaja (Sciaenidae), dan kuro (Polynemidae) (Iskandar et al., 1993). Di perairan timur Aru sampai dengan sebelah barat Aika-Mimika banyak diperoleh ikan kakap merah, kerapu, tenggiri, kembung, dan cumi-cumi (Sumiono, 1982). Hasil penelitian bulan Nopember 2000 di perairan Laut Arafura memperoleh rasio udang terhadap ikan demersal 1:12.

Hasil penelitian bulan Oktober sampai dengan Desember 2002 menggunakan Kapal Riset atau Kapal Latih Madidihang II, di perairan Arafura diperoleh hasil tangkapan sampingan sangat dominan, yaitu 98,31\% dari total tangkapan trawl, sedangkan udang yang menjadi tujuan utama penangkapan hanya $2 \%$ (Tabel 1 ).

Bila diasumsikan rata-rata kapal udang (traw) mampu menangkap atau menampung udang $100 \mathrm{~kg}$ per hari, berarti ikan hasil tangkapan sampingan yang dibuang ke laut mencapai sekitar 5.000 kg per hari 
Tabel1. Komposisi hasil tangkapan traw/Kapal Riset Madididihang II di perairan Arafura berdasarkan pada kelompok jenis ikan, tahun 2002

\begin{tabular}{clccc}
\hline No. & & Kelompok & Volume (kg) & Persentase (\%) \\
\hline 1 & lkan demersal & & $7.315,27$ & 53,05 \\
2 & lkan pari & & $2.175,81$ & 15,78 \\
3 & Kepiting & $1.383,55$ & 10,03 \\
4 & lkan rucah & $1.000,96$ & 7,26 \\
5 & lkan pelagis & 871,75 & 6,32 \\
6 & Invertebrata & 476,19 & 3,45 \\
7 & Udang & 232,79 & 1,69 \\
8 & Sotong & 200,50 & 1,45 \\
9 & Cumi-cumi & & 62,17 & 0,45 \\
10 & Cucut & & 61,15 & 0,44 \\
11 & Lobster & & 10,90 & 0,08 \\
\hline & Total & $\mathbf{1 3 . 7 9 1 , 0 3}$ & $\mathbf{1 0 0 , 0 0}$ \\
\hline
\end{tabular}

per kapal traw/pada periode tersebut. Pada kapal trawl atau pukat ikan yang beroperasi di perairan Arafura mencapai lebih dari 1.100 buah (Anonymous, 2001). Akibat buangan hasil tangkapan sampingan trawl tersebut dikhawatirkan dapat merusak lingkungan perairan tersebut (Gambar 3).

Beberapa kemungkinan akibat hasil tangkapan sampingan yang dibuang kembali ke laut adalah:

1. Dimakan jenis ikan lain (mamalia, kakap, dan lainlain).

2. Dimakan burung (bangau, elang laut, dan lainlain).

3. Dimakan crustasea lain (kepiting, rajungan, udang, dan lain-lain).

4. Membusuk (mencemari lingkungan).

Dari ke-4 fenomena akibat buangan hasil tangkapan sampingan tersebut, akibat yang dominan adalah membusuk dan bercampur kembali dengan perairan di mana operasi penangkapan berlangsung. Dengan demikian, terjadi penurunan daya dukung perairan juga sangat besar.

\section{DAMPAK TERHADAP PENANGKAPAN UDANG}

Akibat meningkat perkembangan traw/ dan hasil tangkapan sampingan yang dibuang kembali ke laut di perairan Arafura, berdampak terhadap penurunan kuantitas dan kualitas udang yang tertangkap. Hasil tangkapan udang secara umum menurun dan ukuran udang juga menjadi lebih kecil.

Dominasi spesies udang juga akan berubah, udang windu (Penaeus monodon) yang semula merupakan hasil tangkapan primadona dengan hasil tangkapan yang cukup tinggi, akhir-akhir ini mulai berkurang. Hasil tangkapan udang mulai didominasi oleh udang putih (Penaeus merguiensis) dan udang ende (Metapenaeus endevoury), udang dogol (Metapenaeus ensis). Bahkan udang krosok yang semula tidak diekspor, kini udang tersebut juga sudah menjadi komoditi ekspor.

Daerah penangkapan udang mulai bergeser, dalam rangka pencarian sumber daya (fishing ghround) yang baru. Bahkan operasional traw/ mulai berpindah ke wilayah perairan yang dilarang, yaitu mencapai

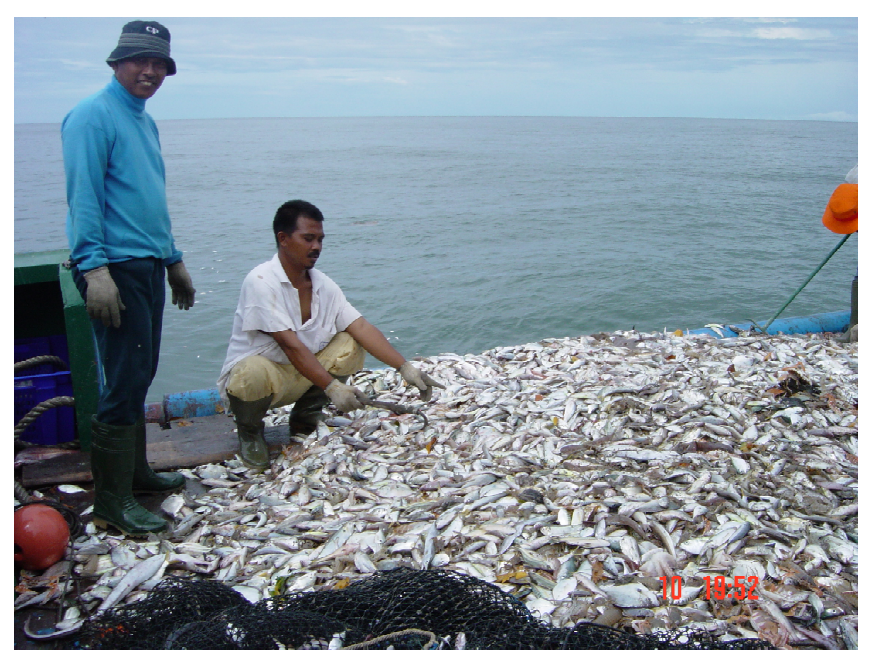

Gambar 3. Hasil tangkapan sampingan (by catch) di atas kapal traw/ yang dibuang kembali ke laut. 
perairan dangkal, muara sungai, perairan pantai, dan lain-lain.

\section{DAMPAK TERHADAP PERKEMBANGAN USAHA PERIKANAN BUDI DAYA}

Perkembangan usaha penangkapan udang menggunakan alat tangkap traw/ di perairan Arafura, apabila tidak terkendali sangat memungkinkan sumber daya perikanan tangkap semakin menurun (over fishing), hilang atau berkurang fishing ground dan spawning ground, atau penurunan daya dukung perairan (carying capacity). Akibat hal tersebut sangat memungkinkan nelayan penangkap ikan akan beralih usaha untuk memanfaatkan perairan yang subur, tenang, terlindung, dan aman untuk usaha perikanan pantai khusus perikanan budi daya.

Wilayah pantai di Papua mempunyai lahan yang sangat luas, dan perairan merupakan sumber induk udang windu, yang merupakan salah satu spesies udang yang mempunyai nilai ekonomis tinggi, sehingga pengembangan usaha budi daya udang dapat dikembangkan di daerah tersebut. Wilayah perairan laut yang terlindung dan yang sesuai untuk usaha budi daya laut dengan sistem karamba jaring apung juga cukup luas, sumber daya induk ikan budi daya tersedia. Ketersediaan bahan baku pakan untuk ikan budi daya, yaitu banyak ikan hasil tangkapan sampingan dari usaha penangkapan trawlyang tidak dimanfaatkan, maupun semakin meningkat populasi kepiting yang semua dapat digunakan sebagai bahan baku pakan (tepung ikan) maupun pakan segar.

\section{KESIMPULAN}

1. Komposisi hasil tangkapan krustasea, menunjukkan bahwa proporsi rajungan, kepiting, dan udang mantis adalah sangat dominan (88\%), dibanding udang komersial yang ukuran relatif lebih besar, maupun udang non ekonomis yang ukuran relatif lebih kecil.

2. Perairan Laut Arafura sampai dengan saat ini merupakan daerah penangkapan udang yang potensial untuk kebutuhan ekspor, mengingat banyak kapal komersial (traw) yang beroperasi di daerah perairan tersebut dengan hasil yang relatif besar. Namun, apabila tidak dilakukan pengawasan dan kebijakan yang memadai, dikhawatirkan akan terjadi over fishing di daerah tersebut.

3. Perikanan budi daya adalah merupakan alternatif pengembangan usaha, baik pada skala usaha penangkapan sudah mengalami penurunan, maupun dalam taraf memanfaatkan hasil tangkapan sampingan yang kini terbuang percuma yang banyak dilakukan oleh kapal trawl yang beroperasi di perairan Laut Arafura.
Persantunan:

Hasil dari kegiatan riset Arafura T.A. 2002-2003

di Balai Riset Perikanan Laut

\section{DAFTAR PUSTAKA}

Allsopp, W. H. L. 1982. Use of fish by catch from shrimp trawling: Future development. In Fish by catch bonus from the sea: Report of a technical consultation on shrimp by catch utilization held in Georgetown. Guyana. 27-30 October 1981. Ottawa. Ont. IDRC: 29-50.

Anonymous. 2001. Evaluasi penangkapan ikan di perairan ZEEI Arafura: Pengkajian sumber daya ikan demersal. Ed. Widodo J., Purwanto, \& Nurhakim S. Direktorat Jenderal Perikanan. Departemen Kelautan dan Perikanan.

Naamin, N. 1984. Dinamika populasi udang jerbung (Penaeus merguiensis de Man) di perairan Arafura dan alternatif pengelolaannya. Disertasi Doktor. Fakultas Pasca Sarjana Institut Pertanian Bogor. Bogor. 281 hal.

Anonymous. 2001. Evaluasi penangkapan ikan di perairan ZEEI Arafura: Pengkajian sumber daya ikan demersal. Ed. Widodo. J., Purwanto, \& Nurhakim S. Direktorat Jenderal Perikanan. Departemen Kelautan dan Perikanan.

Iskandar, B., Sumiono B., \& Sarjana. 1993. Penelitian potensi udang dan hasil tangkap sampingan di perairan Maluku dan Irian Jaya. Laporan Penelitian Balai Penelitian Perikanan Laut. (Tidak dipublikasikan).

Naamin, N. \& B. Sumiono. 1983. Hasil sampingan (by catch) pada penangkapan udang di perairan Laut Arafura dan sekitarnya. Laporan Penelitian Perikanan Laut. No.24/1982. Balai Penelitian Perikanan Laut. Jakarta. 45-55.

Pauly, D. \& R. Neal. 1985. Shrimp vs Fish in Southeast Asian: The biological, technological, and social problems In Arancibia, A. Y (Eds.): Recources Pesqueros de Mexico: La pasca acompanante del camaran. Progr. Univ. de Alimentos. Inst. Cienc. Del Mar. Y. Limnol. Inst. Nacl. De Peasca. UNAM. Mexico. D. F: 748 p.

Sumiono, B. 1982. Survai udang dengan K.M. Binama VIII di perairan Arafura. September 1982. Laporan Survai Balai Penelitian Perikanan Laut. 12 hal. (Tidak diterbitkan).

Widodo, J. 1997. Laporan survei pengamatan sumber daya perikanan demersal menggunakan K.M. Bawal Putih II di perairan kawasan timur Indonesia (Nopember 1995 sampai dengan April 1996). BPPI Semarang. (Tidak diterbitkan). 